\title{
REUTILIZATION OF RECYCLED CONCRETE AS CONCRETE COARSE AGGREGATE
}

\author{
Ayman Gamal* and Faiz A. Mirza ** \\ * Engineering Materials Dep., Faculty of Engineering, \\ Zagazig University, Zagazig, EGYPT. \\ ** Civil Engineering Dep., Faculty of Engineering and Islamic Arch. \\ Umm - Elqura University, Maka, SUADI ARABIA
}

\begin{abstract}
Demolished concrete which became million tons annually, so reuse of these concrete represents a new source of aggregate. The aim of this paper is to study experimentally the effect of using recycled crushed concrete as a coarse aggregate in concrete mix. The main variables considered in this study were the recycled concrete aggregate (RCA) content $(0,25,50,75$ and $100 \%$ by weight) as substitution of natural aggregate (NA) and Cement content $\left(250,300,350\right.$ and $\left.400 \mathrm{~kg} / \mathrm{m}^{3}\right)$. The strength development under compressive and tensile stresses was measured. Test results showed that the behavior of concrete that contained recycled concrete aggregate and that contained natural aggregate are nearly the same uinder compression and tension stress. The compressive strength increases by increasing the recycled aggregate content from $25 \%$ up to $100 \%$. The tensile strength has optimum value at $50 \%$ recycled concrete aggregate content. Also it was found that the compressive and tensile strengths of recycled concrete aggregate specimens were increased by increasing cement content from $250 \mathrm{~kg} / \mathrm{m}^{3}$ up to $400 \mathrm{~kg} / \mathrm{m}^{3}$. This is mainly due to the high reactivity of the recycled concrete and cause alkali-silica bi-reaction.

تهدف هذه الدراسة العملية الحاليه اللى إعادة إبتخدام الخرسانه اللهالكه و التخلص منها في عمل خرسانه جديــــه

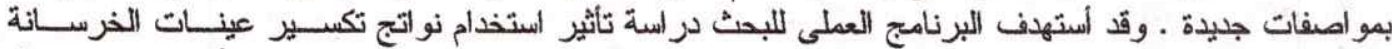

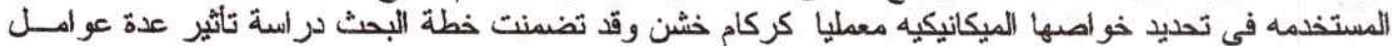

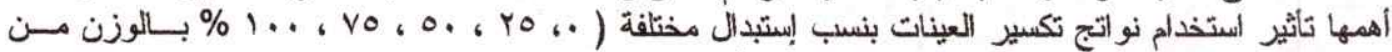

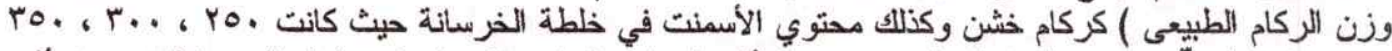

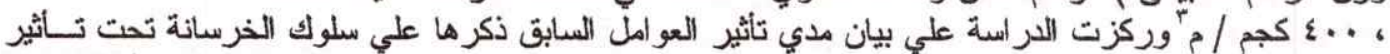

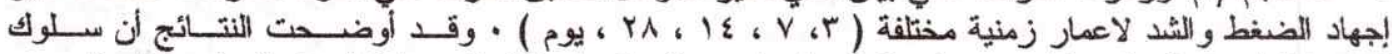

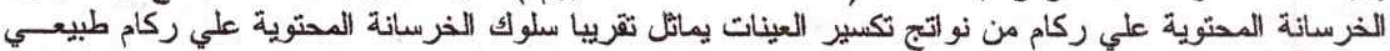

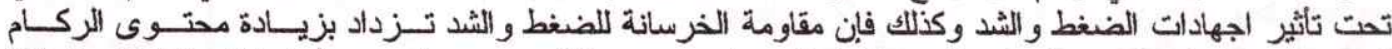

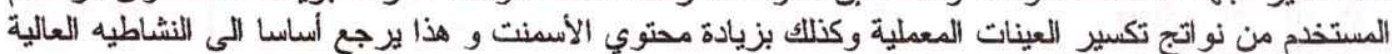

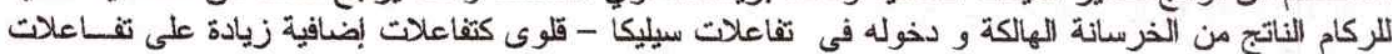

Keywords: Recycled concrete, Aggregate, Cement, Strengths.

\section{INTRODUCTION}

Use of wastes or by-products as aggregate has great potential because $75 \%$ of concrete is composed of aggregates. However, various materials such as gravel, slags, burnt clay can be used as fine or course aggregate. Concrete is the major contributor, to construction and demolition waste that makes up to around $40 \%$ of the total waste that ends up in a landfill. The most common sources of waste are from demolished concrete structures, fresh batch leftovers and waste concrete cubes that have been tested for compliance with building specifications. Therefore, many researches are conducted in the field of recycling concrete. Based on tests carried out on different mixes, many investigations attempt to develop data especially on the strength, failure mechanism, and durability characteristics of the recycled aggregate in comparison with conventional concrete [1-4]. These investigations covered the following aspects: i) An evaluation of typical demolished local concrete rubble in terms of its suitability as aggregate material source. ii) Development of data on some of the engineering properties of fresh and hardened concrete made from recycled material for different $\mathrm{w} / \mathrm{c}$ ratios and cement contents. iii) Comparison with conventional control 
mixes in terms of strength, deformation and durability characteristics for various $w / c$ ratio and different cement content. The results showed that for a $\mathrm{w} / \mathrm{c}$ of 0.35 , the recycled aggregate concrete had $30 \%$ lower strength than that of the reference concrete. The strength differential was narrowed by increasing $\mathrm{w} / \mathrm{c}$ ratios until the strengths were about equal for a w/c ratio of 0.55 . Variability of recycled concrete aggregate and its effects on the properties of concrete was studied $[5,6]$. Creation of buildings with industrial made concrete containing recycled aggregate was tried [7]. Use of recycled concrete aggregate in high s trength c oncrete $w$ as studied [8]. Dhir et al were studied suitability of recycled concrete aggregate for use in BS5328 Designated mixes as well as resolving the application issues with the use of recycled concrete aggregate $[9,10]$. Karlsson et al [11] studied the demolition and recycling of concrete in the Netherlands and also studied reactivity in mortar phase in recycled concrete aggregate. Many studies were evaluated about the use of recycled concrete as a source for a new aggregate $[12,13]$.

Portland cement concrete can be reclaimed during demolition operations and crushed into a coarse granular material that can be used as a substitute for crushed virgin rock. Aggregate processors are beginning to accept reclaimed concrete for a "tipping fee" significantly lower than the cost of 1 and filling the material and to supply recycled concrete aggregate of sufficient quality for many applications. The influence of aggregate derived from recycled mineral building material on the stress-strain relation of concrete was studied $[14,15]$. The concrete mixtures consist of natural dense aggregate, aggregate derived from concrete demolition and brick demolition materials with different $\mathrm{g}$ rain s izes and varying quantities. All concrete mixtures containing the same cement type, and w/c ratio.

The results showed that the deformation of the test samples increasing with raising the amount of recycled demolition material. Aggregate derived from recycled clay, has the highest influence. The deformation under maximum stress for concrete made of $100 \%$ recycled concrete rubble is $20 \%$ higher than the deformation of concrete made of 100 $\%$ natural dense aggregate. By replacing $100 \%$ of the natural aggregate by recycled clay, the deformation rises about $30 \%$. No definite changes in the compressive strength of concrete with recycled demolition aggregate compared to that with $100 \%$ natural dense aggregate were observed [15].

Recycled concrete aggregate is increasingly available and is often an economical alternative to new aggregate. Project managers can ensure that their contractors are aware of opportunities to recycle this material and can require the use of recycled material in construction. Users of recycled concrete aggregate should take customary precautions to ensure that the material is suitable for the intended application.

The main objective of this study is to investigate the effect of using crushed waste concrete as coarse aggregate in concrete on the development of concrete strength for different cement content.

\section{EXPERIMENTAL PROGRAM}

Within the scope of this study, different concrete mixtures were manufactured to determine the influence of aggregate derived from recycled mineral building material referring to tensile and compressive strength of concrete. These concrete mixtures consist of natural dense aggregate, aggregate derived from concrete demolition. All concrete mixtures contained the same cement-type, cement quality and watercement-ratio. The main variables, material properties, experiments on recycled and natural aggregate, mix design, casting and tested models are described as follows:

\section{Variables}

All concrete mixtures c ontained the s ame cementtype, cement quality and water-cement-ratio equals to 0.5 . The main variables considered in this study were the content of recycled aggregate $(0,25,50,75$ and $100 \%$ by weight) as substitution of natural aggregate and the cement content $(250,300,350$ and 400 $\mathrm{kg} / \mathrm{m}^{3)}$ as reported in Table (1).

\section{Materials properties}

A locally produced ordinary Portland cement (Type I) was used in this investigation. Recycled concrete aggregates with nominal maximum size of $20 \mathrm{~mm}$ $(0.8 \mathrm{in})$ were used as coarse aggregate. These aggregates were brought from quality control lab test samples of ready mixed concrete plant. The aggregates were crushed by hand into small pieces and separated from fine aggregate by using sieve No.4. Natural aggregate (crushed stone) was used; it was free from any undesirable impurities and with aggregate of size $20 \mathrm{~mm}$. Natural fine clean sand free from any impurities such that silt, clay and organic compounds was used. The fine aggregate was confirmed the ASTM requirements (ASTM C-33) [16].The water that used in mixing and curing of all concrete mixes and specimens was clean fresh water free from any impurities. The used superplasticizer is based on selected sulphonated naphthalene polymers and is free from chlorides. It is supplied as a brown solution which instantly disperses in water.

\section{Specimens and Test procedure}

The primary tests such as specific gravity, unit weight, water absorption and Los Angeles were 
carried out for both RCA and NA. Internationally, the most frequently used paste for aggregate abrasion resistance is probably that employing the Los Angeles apparatus [17].

The compression and splitting tensile tests were carried out according to B.S. 1881.52 [18], on standard cubes $(15 \times 15 \times 15 \mathrm{~cm})$ and standard cylinders $(15 \mathrm{~cm}$ in diameter and $30 \mathrm{~cm}$ in height). Three cubes and cylinders were cast form each mix and cured in clean water for 28 days. The crushing load was recorded to determine the compressive strength or splitting tensile strength of concrete samples using compression testing machine.

\section{RESULTS AND DISCUSSIONS}

It is known that the physical properties of the concrete aggregate as specific gravity, water absorption and moisture content play an important role on the ultimate aggregate reactivity for aggregate cement bond strength. Table (2) shows the primary test r esults for these $\mathrm{c}$ haracteristics of $\mathrm{b}$ oth types of the aggregate used in this investigation. The specific gravity for natural aggregate (crushed stone) and recycled concrete aggregate were nearly equal, while the water absorption of recycled concrete aggregate (highly porous) was about two times the water absorption of natural aggregate.

Table 1: Experimental program.

\begin{tabular}{|c|c|c|c|c|c|c|c|c|c|}
\hline \multirow{3}{*}{$\begin{array}{l}\text { Recycled } \\
\text { Concrete } \\
\text { Aggregate } \\
\text { content (\%) }\end{array}$} & \multirow{3}{*}{$\begin{array}{l}\text { Cement } \\
\text { Content } \\
\left(\mathrm{Kg} / \mathrm{m}^{3}\right)\end{array}$} & \multicolumn{4}{|c|}{ Compressive Strength } & \multicolumn{4}{|c|}{ Tensile Strength } \\
\hline & & \multicolumn{8}{|c|}{ Test Age (days) } \\
\hline & & 3 & 7 & 14 & 28 & 3 & 7 & 14 & 28 \\
\hline \multirow{4}{*}{0} & 250 & - & - & - & - & - & - & - & - \\
\hline & 300 & - & - & - & - & - & - & - & - \\
\hline & 350 & - & - & - & - & - & - & - & - \\
\hline & 400 & - & - & - & - & - & - & - & - \\
\hline \multirow{4}{*}{25} & 250 & - & - & - & - & - & - & - & - \\
\hline & 300 & - & - & - & - & - & - & - & - \\
\hline & 350 & - & - & - & - & - & - & - & - \\
\hline & 400 & - & - & - & - & - & - & - & - \\
\hline \multirow{4}{*}{50} & 250 & - & - & - & - & - & - & - & - \\
\hline & 300 & - & - & - & - & - & - & - & - \\
\hline & 350 & - & - & - & - & - & - & - & - \\
\hline & 400 & - & - & - & - & - & - & - & - \\
\hline \multirow{4}{*}{75} & 250 & - & - & - & - & - & - & - & - \\
\hline & 300 & - & - & - & - & - & - & - & - \\
\hline & 350 & - & - & - & - & - & - & - & - \\
\hline & 400 & - & - & - & - & - & - & - & - \\
\hline \multirow{4}{*}{100} & 250 & - & - & - & - & - & - & - & - \\
\hline & 300 & - & 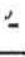 & - & - & - & - & - & - \\
\hline & 350 & - & - & - & - & - & - & - & - \\
\hline & 400 & - & - & - & - & - & - & - & - \\
\hline
\end{tabular}

*Three samples were preformed for each test condition. 
Table 2: Results of primary tests.

\begin{tabular}{|c|c|c|c|}
\hline Experiment & Natural & Recycled & Standard* \\
\hline Specific Gravity & 2.7 & 2.61 & $2.6-2.9$ \\
\hline Water Absorption (\%) & 2.13 & 4.26 & 1.7 \\
\hline Moisture Content $(\%)$ & 2.1 & 2.23 & -- \\
\hline Unit Weight $\left(\mathrm{kg} / \mathrm{m}^{3}\right)$ & 1720 & 1440 & $1750-1800$ \\
\hline Los Angeles $(\%)$ & 37 & 27.28 & $10-45$ \\
\hline
\end{tabular}

* ASTM 1992.

Therefore, the increase of water absorption of recycled concrete must be taken into consideration in the design of concrete mix to avoid absorption of mixing water. The unit weight of the recycled concrete aggregate is also lower than natural aggregate by about $20 \%$, so the density of c oncrete made from recycled aggregate is lower than that made from natural aggregate. This may be due to the higher porosity of recycled concrete aggregate particles compared to natural aggregates. Also it was observed that recycled aggregate give a better results rather than natural aggregate especially in abrasion resistance; this mainly attributed to the presence of well crystalline $\mathrm{c}$ alcium s ilicate hydrate surrounding the aggregate particles in case of recycled concrete causes more aggregate- surface resistance for degradation.

The physical and mechanical properties of concrete made with recycled concrete aggregate appear generally inferior to those of comparable concretes made using high quality natural aggregate [19]. Table (3) shows the average compressive and tensile strength test results. These data were graphically represented in Figs. $(1,2)$, it explains the effect of recycled aggregate content at different cement contents on compressive and tensile strength, respectively. At $250 \mathrm{~kg} / \mathrm{m}^{3}$ and $300 \mathrm{~kg} / \mathrm{m}^{3}$ cement content, the compressive strength has a higher value at $50 \%$ recycled concrete aggregate. While with using $350 \mathrm{~kg} / \mathrm{m}^{3}$ cement content, the compressive strength of recycled concrete was increased with the increase in the percent of recycled aggregate, and showed the highest value at $100 \%$ recycled concrete aggregate. Similar observation was found for tensile strength with little effect of recycled concrete aggregate content. For cement content 350 and 400 $\mathrm{kg} / \mathrm{m}^{3}$, the higher value of tensile strength was recorded at $50 \%$ of recycled concrete aggregate, this is due to the presence of some remaining calcium silicate hydrates (C-S-H), which acting as nuclease for the more formation and accumulation for more silicate compounds resulting well crystalline network and finally good cement aggregate bond strength. Generally, the compressive strength of the concrete with recycled aggregate is better than that observed with natural aggregate used.

The compressive strength of recycled concrete aggregate specimens was plotted for different cement contents in Figs. (3-6). Generally, it was observed that the behavior of recycled concrete aggregate specimens under compression is similar for all recycled aggregate contents $(0,25,50,75$, and $100 \%$ ), and the rate of strength gaining was nearly the same and equal to 0.5 . Also, it was found that with increasing cement content the compressive strength increases by a higher values than that recorded for $0 \%$ recycled concrete aggregate, specially at cement contents of 300 and $350 \mathrm{~kg} / \mathrm{m}^{3}$, this is mainly due to the more cement hydration products which responsible to the concrete strength. The rate of strength gaining up to 7 days was higher than that occurred after at 28 days.

Similar behavior was observed for all types of concrete specimens and the rate of strength gaining was nearly the same and equal to 0.6 for $400 \mathrm{~kg} / \mathrm{m}^{3}$ cement content recycled concrete aggregate mixture and it can be concluded that there is no any negative effect of using recycled concrete aggregate by any ratio on the development of concrete compressive strength up to 28 days.

The behavior of recycled concrete aggregate specimens under tension for different ratios of recycled concrete aggregate content was presented in Figs. (7-10) for cement content 250, 300, 350 and $400 \mathrm{~kg} / \mathrm{m}^{3}$, respectively. It was observed that the tensile strength increased by nearly constant rate up to 28 days for all cement contents and different ratios of recycled concrete aggregate. Also, specimens contained $50 \%$ recycled concrete aggregate showed a better behavior for cement contents of 250 and 300 $\mathrm{kg} / \mathrm{m}^{3}$ rather than for $350 \mathrm{~kg} / \mathrm{m}^{3}$ cement content. The tensile strength of recycled concrete aggregate specimens was greater than or nearly equal to that 
recorded for normal concrete specimens of $0 \%$ recycled concrete aggregate.

For $400 \mathrm{~kg} / \mathrm{m}^{3}$ cement content, similar behavior for all types of concrete specimens up to 7 days was observed, except at $25 \%$ recycled concrete aggregate. The rate of strength gaining was nearly increased, while for $25 \%$ recycled concrete aggregate was decreased. After 7 days and up to 28 days, the rate of strength gaining was nearly increased.

There are an observable influence of recycled aggregate core moisture on freshly and hardened concrete properties [20.21]. Indeed some porous aggregates similar to recycled concrete aggregate can have beneficial influence, for example by acting as a water reservoir to assist later hydration of cement.

Table 3 : Average compressive and tensile test results

\begin{tabular}{|c|c|c|c|c|c|c|c|c|c|}
\hline \multirow{3}{*}{$\begin{array}{c}\text { Recycled } \\
\text { Concrete } \\
\text { Aggregate } \\
\text { content } \\
(\%)\end{array}$} & \multirow{3}{*}{ 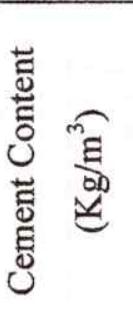 } & \multicolumn{4}{|c|}{ Compressive Strength, $\mathrm{MPa}$} & \multicolumn{4}{|c|}{ Tensile Strength, $\mathrm{MPa}$} \\
\hline & & \multicolumn{4}{|c|}{ Test Ages ( Days ) } & \multicolumn{4}{|c|}{ Test Ages ( Days ) } \\
\hline & & 3 & 7 & 14 & 28 & 3 & 7 & 14 & 28 \\
\hline \multirow{4}{*}{0} & 250 & 15.16 & 16.94 & 24.39 & 28.50 & 1.19 & 1.93 & 2.14 & 2.73 \\
\hline & 300 & 16.90 & 21.72 & 24.64 & 29.40 & 1.42 & 1.80 & 2.28 & 2.80 \\
\hline & 350 & 19.95 & 26.54 & 27.87 & 28.80 & 1.75 & 2.03 & 2.54 & 3.53 \\
\hline & 400 & 27.44 & 30.46 & 36.60 & 46.73 & 2.20 & 2.41 & 2.91 & 3.63 \\
\hline \multirow{4}{*}{25} & 250 & 16.43 & 21.73 & 24.84 & 29.91 & 1.25 & 1.80 & 2.18 & 2.63 \\
\hline & 300 & 19.03 & 24.41 & 28.00 & 34.25 & 1.54 & 1.97 & 2.54 & 2.90 \\
\hline & 350 & 22.93 & 25.79 & 30.22 & 36.95 & 1.79 & 2.10 & 2.54 & 3.14 \\
\hline & 400 & 23.49 & 26.75 & 31.65 & 37.61 & 2.00 & 2.04 & 2.61 & 3.30 \\
\hline \multirow{4}{*}{50} & 250 & 19.34 & 22.05 & 26.37 & 31.84 & 1.59 & 1.92 & 2.73 & 2.85 \\
\hline & 300 & 23.64 & 28.20 & 32.95 & 39.26 & 1.93 & 2.20 & 3.11 & 3.22 \\
\hline & 350 & 22.19 & 28.67 & 34.41 & 40.56 & 1.80 & 2.35 & 3.01 & 3.35 \\
\hline & 400 & 25.23 & 31.68 & 33.07 & 39.43 & 2.02 & 2.51 & 3.21 & 3.55 \\
\hline \multirow{4}{*}{75} & 250 & 16.90 & 22.09 & 22.45 & 29.78 & 1.47 & 2.09 & 2.23 & 2.46 \\
\hline & 300 & 20.52 & 27.46 & 29.56 & 33.36 & 1.79 & 2.43 & 2.45 & 2.72 \\
\hline & 350 & 25.26 & 30.84 & 32.82 & 36.61 & 2.04 & 2.60 & 3.12 & 3.19 \\
\hline & 400 & 26.61 & 31.51 & 37.75 & 43.51 & 2.14 & 2.92 & 3.01 & 3.31 \\
\hline \multirow{4}{*}{100} & 250 & 15.29 & 21.79 & 22.59 & 24.59 & 1.24 & 1.57 & 1.87 & 2.31 \\
\hline & 300 & 21.85 & 28.96 & 33.10 & 34.58 & 1.55 & 2.38 & 2.48 & 2.58 \\
\hline & 350 & 27.90 & 32.83 & 37.01 & 41.13 & 2.16 & 2.17 & 2.57 & 2.95 \\
\hline & 400 & 24.42 & 33.33 & 38.47 & 40.41 & 1.71 & 2.57 & 2.79 & 3.10 \\
\hline
\end{tabular}




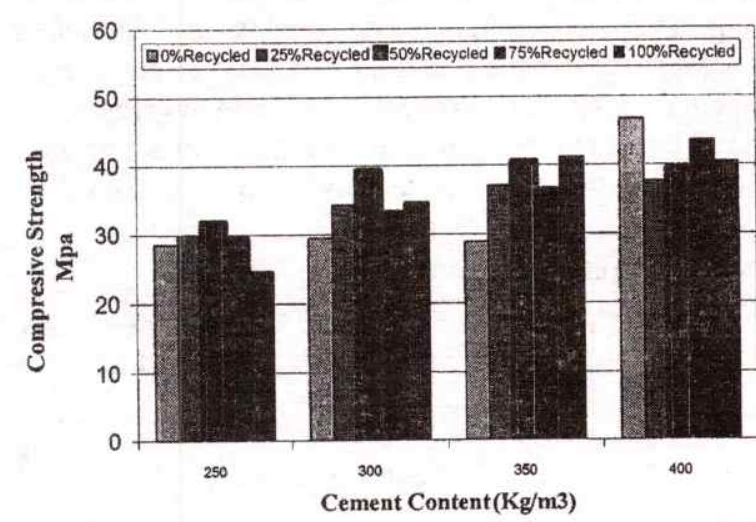

Fig. (1): Compressive strength of concrete for different ratios of recycled concrete aggregate with different cement content.

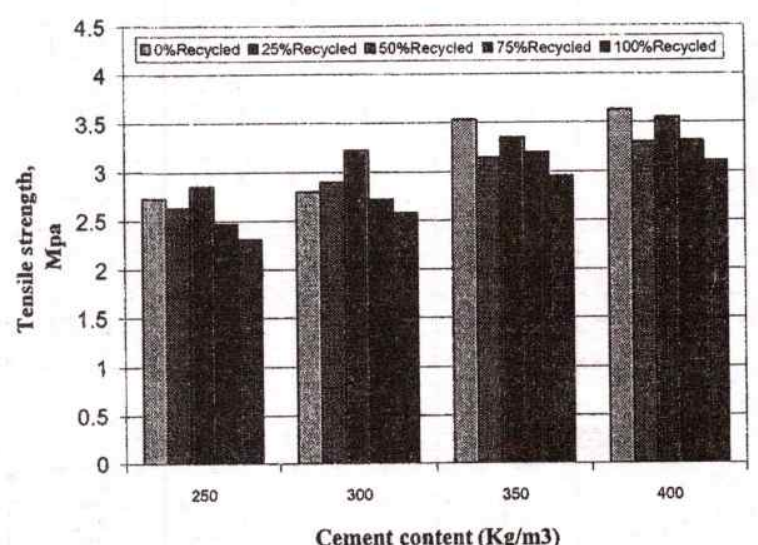

Fig. (2): Tensile strength of concrete for different ratios of recycled concrete aggregate with different cement content.

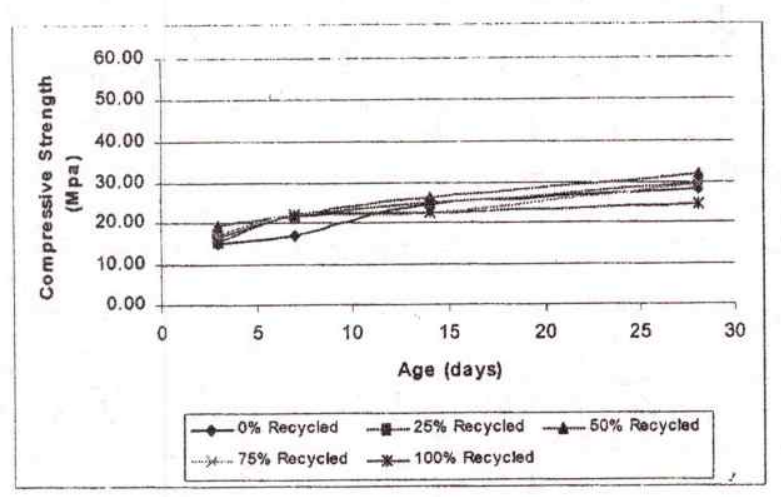

Fig. (3): Development of concrete compressive strength of recycled concrete aggregate mix at $250 \mathrm{~kg} / \mathrm{m}^{3}$ cement content.

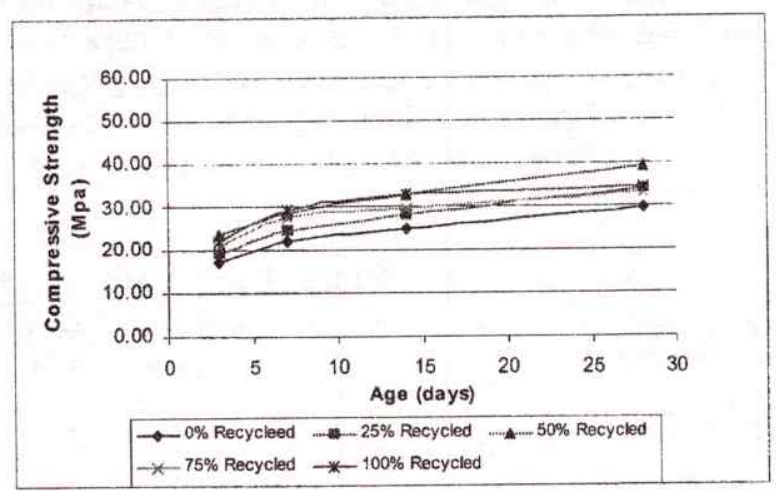

Fig. (4): Development of concrete compressive strength of recycled concrete aggregate $\operatorname{mix}$ at $300 \mathrm{~kg} / \mathrm{m}^{3}$ cement content

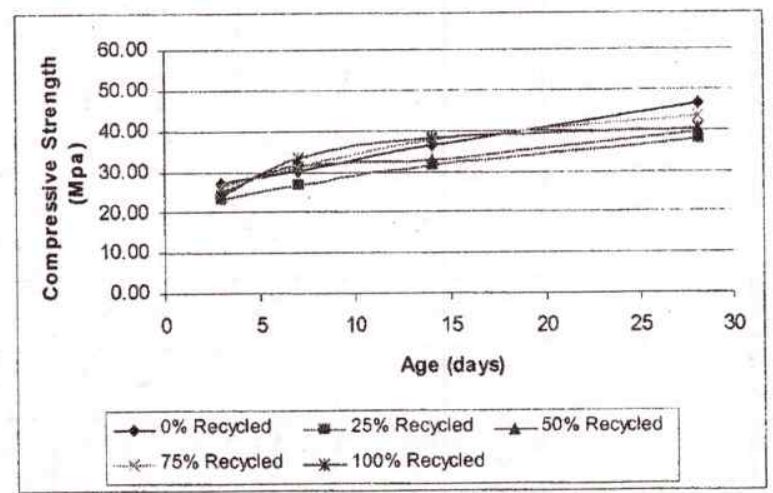

Fig. (5): Development of concrete compressive strength of recycled concrete aggregate $\operatorname{mix}$ at $350 \mathrm{~kg} / \mathrm{m}^{3}$ cement content

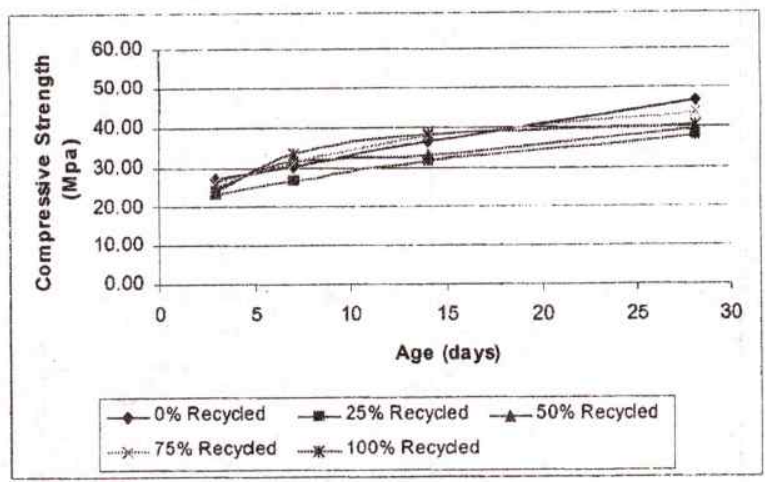

Fig. (6): Development of concrete compressive strength of recycled concrete aggregate mix at $400 \mathrm{~kg} / \mathrm{m}^{3}$ cement content 


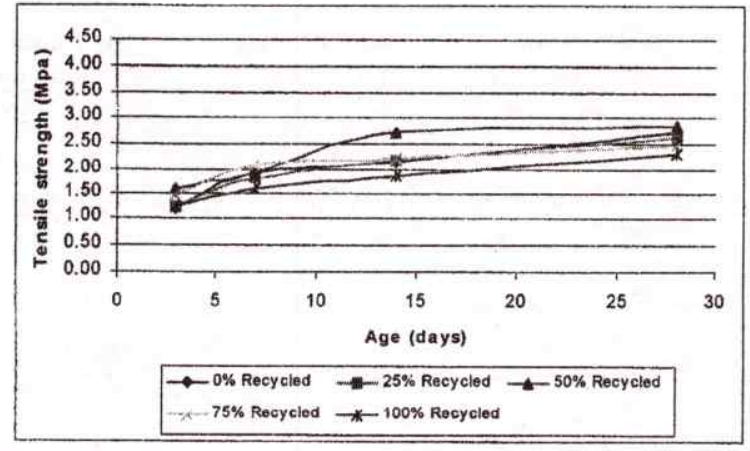

Fig. (7): Development of concrete Tensile Strength of recycled concrete aggregate mix at 250 $\mathrm{kg} / \mathrm{m} 3$ cement content

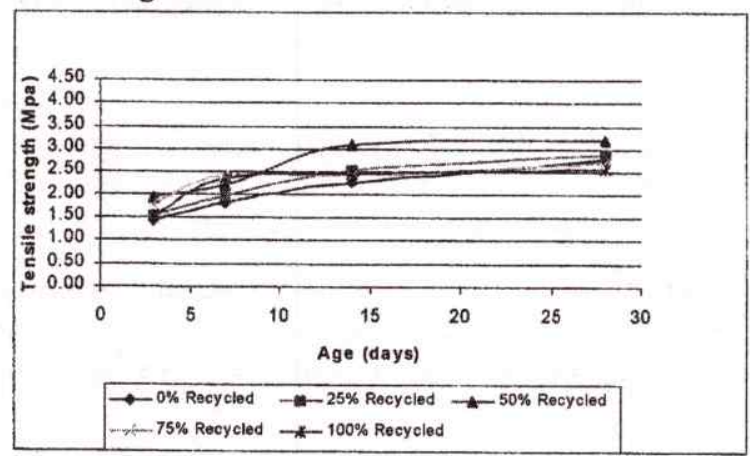

Fig. (8): Development of concrete Tensile Strength of recycled concrete aggregate mix at 300 $\mathrm{kg} / \mathrm{m} 3$ cement content

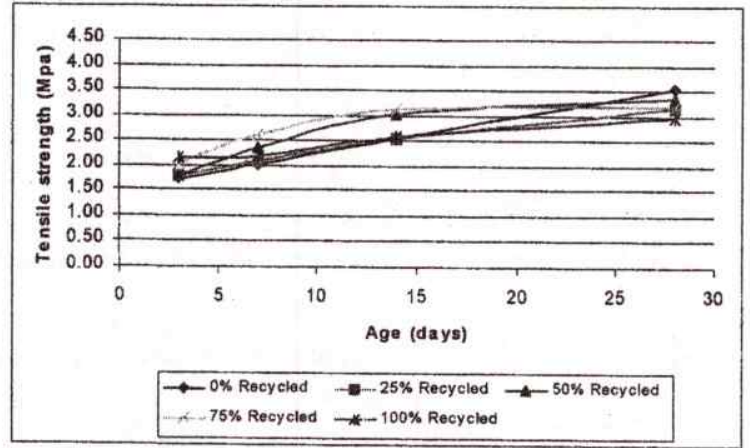

Fig. (9): Development of concrete Tensile Strength of recycled concrete aggregate mix at 350 $\mathrm{kg} / \mathrm{m} 3$ cement content.

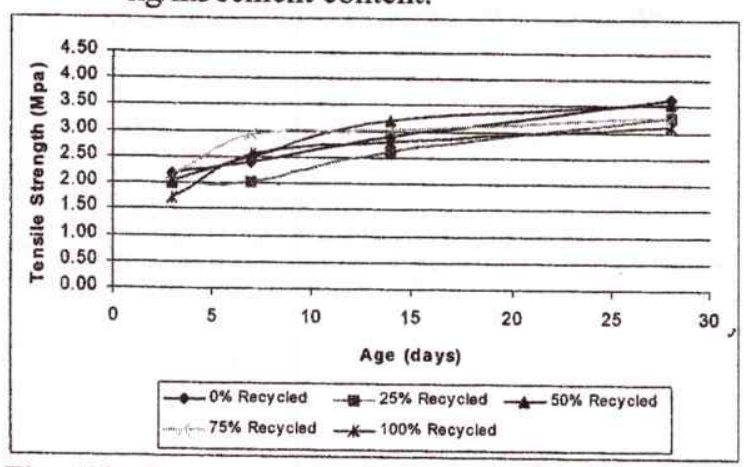

Fig. (10): Development of concrete Tensile Strength of recycled concrete aggregate mix at 400 $\mathrm{kg} / \mathrm{m} 3$ cement content.

\section{CONCLUSIONS}

Based on the results of present study, the following conclusions can be drown:

1- The realized inquests give an answer to the question, if the used aggregate causes some negative effects on the compressive strength.

2- The result of this study shows, that there is little decrease in the compressive strength, when aggregate derived from recycled concrete is used. Building components made of concrete with recycled aggregate, can be designed with the same characteristic values as components of concrete made with natural aggregate.

3- Portland cement concrete can be reclaimed during demolition operations and crushed into a coarse granular material that can be used as a substitute for crushed virgin rock. The behavior of concrete made from recycled concrete aggregate and natural aggregate were nearly the same under compression and tension test.

4- The compressive strength of recycled concrete was increased by increasing the recycled aggregate content from $25 \%$ up to $100 \%$, but still lower than that obtained from natural aggregate by about $13.5 \%$.

5- The tensile strength had an optimum value at 50\% recycled concrete aggregate content, but still less than that obtained from natural aggregate mixture by about $17 \%$. Increasing cement content from 250 $\mathrm{kg} / \mathrm{m}^{3}$ up to $400 \mathrm{~kg} / \mathrm{m}^{3}$ increased the compressive and tensile strength of recycled concrete aggregate specimens.

\section{References}

[1] A. Bretschneider and M. Ruhl, "The influence of recycled aggregate on the compressive strength and the elastic modulus of concrete", Aus dem Berichtshend zu drmstadt concrete, 1998.

[2] M. Baratta and D. Becker-Rose, "Moisture Measuring on Recycled Aggregates", Aus dem Berichtshend zu drmstadt concrete, 1998.

[3] A. R. M. Ridzuan ${ }^{1}$, M. A. Jelani ${ }^{1}$ and A. M. $\mathrm{Diah}^{2}$, "Influence of Recycled Aggregates on the Performance and Durability of OPC Concrete", ${ }^{1}$ Fuclty of civil engineering, Mara University of Technology, Shah Alam, Malaysia, ${ }^{2}$ School of civil engineering, science university of Malaysia, 2002

[4] R. Sri Ravindrarajah, C. T. Tam and Y. H. Loo, "Recycling Concrete as Aggregate for New Concrete, Proc. of the Int. Symp. '92 on Solid Waste Recycling Technology, 16-17 Sept. 1992, Seoul, Korea, PP 53-72. 
[5] R. Sri Ravindrarajah, M. Stewart and D. Greco, "Variability of recycled concrete aggregate and its effects on the properties of concrete - A case study in Australia, Proceedings of the International Seminar on Recycled Concrete, 29th Sept. 2000, Niigata, Japan, PP 9-26.

[6] R. Sri Ravindrarajah, M. Stewart and D. Greco, "Variability of recycled concrete aggregate and its effects on the properties of concrete, Proceedings of the Second International Conference on Engineering Materials, August 2001, San Jose, USA.

[7] P. GRÜBL, Die Erstellung von Bauwerken unter Verwendung von industriell gefertigten Betons mit rezykliertem Zuschlag "Creation of Buildings with Industrial made Concrete Containing Recycled Aggregate", 18. Darmstädter Massivbau Seminar, Volume 18, 1997

[8] M. C. Limbachiya T. Leelawat and R. K. Dhir, "Use of Recycled Concrete Aggregate in High Strength Concrete", Materials and Structures, RILEM, Vol. 33, November 2000, PP 574- 580.

[9] R. K. Dhir, M. C. Limbachiya and T. Leelawat, "Suitability of recycled concrete aggregate for use in BS5328 Designated mixes". Institution of Civil Engineers Structs \& Bldgs, 134, Aug.1999, PP 257-274.

[10] R. K. Dhir, M. C. Limbachiya and A. Beggs, "Resolving Application Issues with the Use of Recycled Concrete Aggregate", DETR Report: CTU/1401, University of Dundee, February 2001, P 175.

[11] M. Karlsson, "Demolition and recycling of concrete in the Netherlands", A study trip arranged by Norwegian Concrete Society. Chalmers University of Technology, Division of Building Technology, Work No 20. Publication 98:1. Göteborg January 1998, P 13.

[12] M. Karlsson "Reactivity in Mortar Phase in Recycled Concrete Aggregate", Contribution to
International Symposium, Sustainable construction - "Use of recycled concrete aggregate" in London, 11-12 November 1998. Chalmers University of Technology, Division of Building Technology, Work No 27, Publication 98:5. Göteborg, July 1998, P 7.

[13] Rasheeduzzafar and A. Khan, "Recycled Concrete - A Source for a New Aggregate", Cement, concrete and Aggregates, CCAGDP, Vol. 6, No.1, 1984.

[14] USGS, "Recycled Aggregate Profitable Resource Conservation", Construction and Demolition Publications, "Recycled Aggregate", California integrated waste management board, 2000.

[15] S. W. Forster, "Recycled concrete as aggregate properties and use of an alternative aggregate" Concrete international 1986; October, PP 34-40.

[16] American Society for Testing and Materials "Standard Specification for Concrete aggregates" Philadelphia, USA: ASTM, 1993; ASTM C33-93.

[17] British Standard Specification, 1881- 52, Methods of Testing Concrete.

[18] American Society for Testing and Materials "Standard test for resistance to degradation for large size coarse aggregate by abrasion and impact in the Los Anglos machine Philadelphia, USA: ASTM, 1993; ASTM C 535- 96.

[19] A. M. Neville "Properties of Concrete", $4^{\text {th }}$ Edition Harlow, UK: Longman Group Limited, 1995.

[20] RÜHL, MARCUS. "Water Absorption Capacity of recycled demolition Rubbish"; Darmstadt Concrete Volume 12, 1997, Darmstadt.

[21] A. Nealan, and S. Scheak, "The Influence of Recycled Aggregate Core Moisture On Freshly and Hardened Concrete Properties"1990. 